\title{
The Performance of Fire Protection of Buildings against the Fires Following the Great Hanshin-Awaji Earthquake
}

\author{
AKIHIKO HOKUGO \\ Building Research Institute \\ Ministry of Construction \\ 1 Tatehara, Tsukuba, 305, Japan
}

\begin{abstract}
High levels of amplitude acceleration ( 300 to $800 \mathrm{~cm} / \mathrm{s}^{2}$ ) and velocity $(80 \mathrm{~cm} / \mathrm{s}$ ) were observed over a wide area at the time of the 1995 Great Hanshin-Awaji Earthquake. The locations where the fires started are almost uniformly distributed in areas where buildings suffered severe structural damage, mainly areas where the seismic intensity reached seven on the JMA (Japan Meteorological Agency) scale.

Thanks to the weak winds at the time of the earthquake, the speed of the fire spread was far below that of past urban fires. Seven large fires that destroyed an area of more than $33,000 \mathrm{~m}^{2}$ each, broke out in areas with large concentrations of wooden houses. Most of the fireprotected wooden buildings that caught fire did so mainly because fire spread through the building's openings, not through their walls. Most of the cease-burning lines in urban areas were wide streets, railways, parks and similar large spaces, rows of buildings of fireproof construction, and fire proof buildings constructed on large building lots. This confirms that it is extremely important to provide more space between buildings and improve buildings' fireproof performance in order to prevent the spread of urban fires following earthquakes.
\end{abstract}

KEYWORDS: earthquake fires, large conflagrations, fire spread mechanisms

\section{LARGE NUMBER OF SIMULTANEOUS IGNITIONS}

During the first 3 days following the earthquake, more than 200 fires occurred in the Hyogo and Osaka prefectures ${ }^{1)}$. Of those, 138 fires took place in Kobe city ${ }^{2)}$. Figure 1 shows 150 fire sites where investigations by Building Research Institute were conducted. The fires started in areas where buildings suffered severe structural damage. Table 1 shows the relationship between the structural damage of the buildings in which the fires started and the causes of fires. As the structural damage become more sever, the number of fires increases. 
TABLE 1. The relationship between the structural damage to the buildings and the causes of fires $^{3)}$.

\begin{tabular}{|c|c|c|c|c|c|c|}
\hline $\begin{array}{l}\text { Degree of } \\
\text { Structural Damage }\end{array}$ & $\begin{array}{l}\text { Number of } \\
\text { Buildings }\end{array}$ & $\begin{array}{l}\text { Gas } \\
\text { Related * }\end{array}$ & $\begin{array}{l}\text { Electricity } \\
\text { Related * }\end{array}$ & $\begin{array}{l}\text { Other } \\
\text { Fires * }\end{array}$ & $\begin{array}{c}\text { Unknown } \\
*\end{array}$ & Total * \\
\hline $\begin{array}{l}\text { Collapsed or } \\
\text { Destroyed }\end{array}$ & 93,567 & $\begin{array}{c}10 \\
(10.7)\end{array}$ & $\begin{array}{c}4 \\
(4.3)\end{array}$ & $\begin{array}{c}11 \\
(11.8)\end{array}$ & $\begin{array}{c}32 \\
(34.2)\end{array}$ & $\begin{array}{c}57 \\
(60.9)\end{array}$ \\
\hline Moderate Damage & 90,908 & $\begin{array}{c}5 \\
(5.5) \\
\end{array}$ & $\begin{array}{c}4 \\
(4.4) \\
\end{array}$ & $\begin{array}{l}1 \\
(1.1) \\
\end{array}$ & $\begin{array}{c}14 \\
(15.4) \\
\end{array}$ & $\begin{array}{c}24 \\
(26.4) \\
\end{array}$ \\
\hline $\begin{array}{l}\text { Slight damage or } \\
\text { undamaged }\end{array}$ & 358,525 & $\begin{array}{c}8 \\
(\quad 2.3) \\
\end{array}$ & $\begin{array}{c}18 \\
(\quad 5.0) \\
\end{array}$ & $\begin{array}{c}11 \\
(\quad 3.1) \\
\end{array}$ & $\begin{array}{c}33 \\
(\quad 9.2) \\
\end{array}$ & $\begin{array}{c}70 \\
(19.5) \\
\end{array}$ \\
\hline Unknown & & 1 & 6 & 5 & 18 & 30 \\
\hline Total & 543,000 & $\begin{array}{l}24 \\
(\quad 4.4) \\
\end{array}$ & $\begin{array}{c}32 \\
(\quad 5.9) \\
\end{array}$ & $\begin{array}{c}28 \\
(\quad 5.2) \\
\end{array}$ & $\begin{array}{c}97 \\
(17.7)\end{array}$ & $\begin{array}{c}181 \\
(33.3)\end{array}$ \\
\hline
\end{tabular}

TABLE 2. Temperature, Wind Velocity, Wind Direction and relative humidity recorded at Kobe Meteorological Observatory in Chuo Ward for the day of the Earthquake, 17 January 1995.

\begin{tabular}{|c|c|c|c|c|}
\hline Time & $\begin{array}{l}\text { Temperature } \\
\left({ }^{\circ} \mathrm{C}\right)\end{array}$ & $\begin{array}{l}\text { Wind Velocity } \\
(\mathrm{m} / \mathrm{s})\end{array}$ & Wind Direction & $\begin{array}{l}\text { Relative } \\
\text { Humidity ( \% ) }\end{array}$ \\
\hline 0100 & 3.5 & 2.2 & ENE & 66 \\
\hline 0200 & 2.9 & 1.1 & $\mathrm{~N}$ & 68 \\
\hline 0300 & 2.6 & 1.3 & NNE & 70 \\
\hline 0400 & 2.7 & 1.7 & $\mathrm{NNE}$ & 70 \\
\hline 0500 & 2.9 & 2.1 & ENE & 69 \\
\hline 0600 & 3.4 & 4.6 & $\mathrm{NE}$ & 54 \\
\hline 0700 & 3.5 & 3.2 & ENE & 56 \\
\hline 0800 & 3.4 & 3.3 & E & 53 \\
\hline 0900 & 3.7 & 3.0 & ENE & 54 \\
\hline 1000 & 4.2 & 2.0 & ESE & 52 \\
\hline 1100 & 4.4 & 1.8 & $\mathrm{E}$ & 54 \\
\hline 1200 & 5.2 & 0.2 & - & 49 \\
\hline 1300 & 6.4 & 2.4 & SE & 43 \\
\hline 1400 & 5.6 & 2.5 & SE & 49 \\
\hline 1500 & 6.5 & 0.4 & SE & 45 \\
\hline 1600 & 6.1 & 6.8 & $\mathrm{~N}$ & 45 \\
\hline 1700 & 5.2 & 2.8 & WNW & 52 \\
\hline 1800 & 3.9 & 3.9 & NNE & 58 \\
\hline 1900 & 3.3 & 4.0 & $\mathrm{~N}$ & 60 \\
\hline 2000 & 3.2 & 4.4 & NNE & 57 \\
\hline 2100 & 3.4 & 2.7 & $\mathrm{NE}$ & 53 \\
\hline 2200 & 3.0 & 1.5 & $\mathrm{NE}$ & 57 \\
\hline 2300 & 3.0 & 3.2 & NNE & 54 \\
\hline 2400 & 1.4 & 1.9 & $\mathrm{~N}$ & 64 \\
\hline
\end{tabular}


In this table, causes of fires are categorized into three groups: gas related fires, electricity related fires and other fires. Gas related fires have a strong correlation to the building damage. Electricity related fires occurred evenly with structural damage. This indicates that gas related fires most likely occurred when the building was collapsed or severely damaged and as the result the gas pipes were cut or unconnected.

\section{LARGE CONFLAGRATIONS}

Of 150 fire sites investigated by BRI, 73 fires involved a single building and 77 involved multiple buildings. The number of fire sites less than $1,000 \mathrm{~m}^{2}$ is 33 . Seven fires spread over $33,000 \mathrm{~m}^{2}$. The other 37 fire sites are between 1,000 and $33,000 \mathrm{~m}^{2}$. Figure 2 shows large conflagrations whose area is over $3,300 \mathrm{~m}^{2}$ in Nagata, Suma, Hyogo, Nada and HigashiNada Ward. See Figure 1 for the relations of the wards.

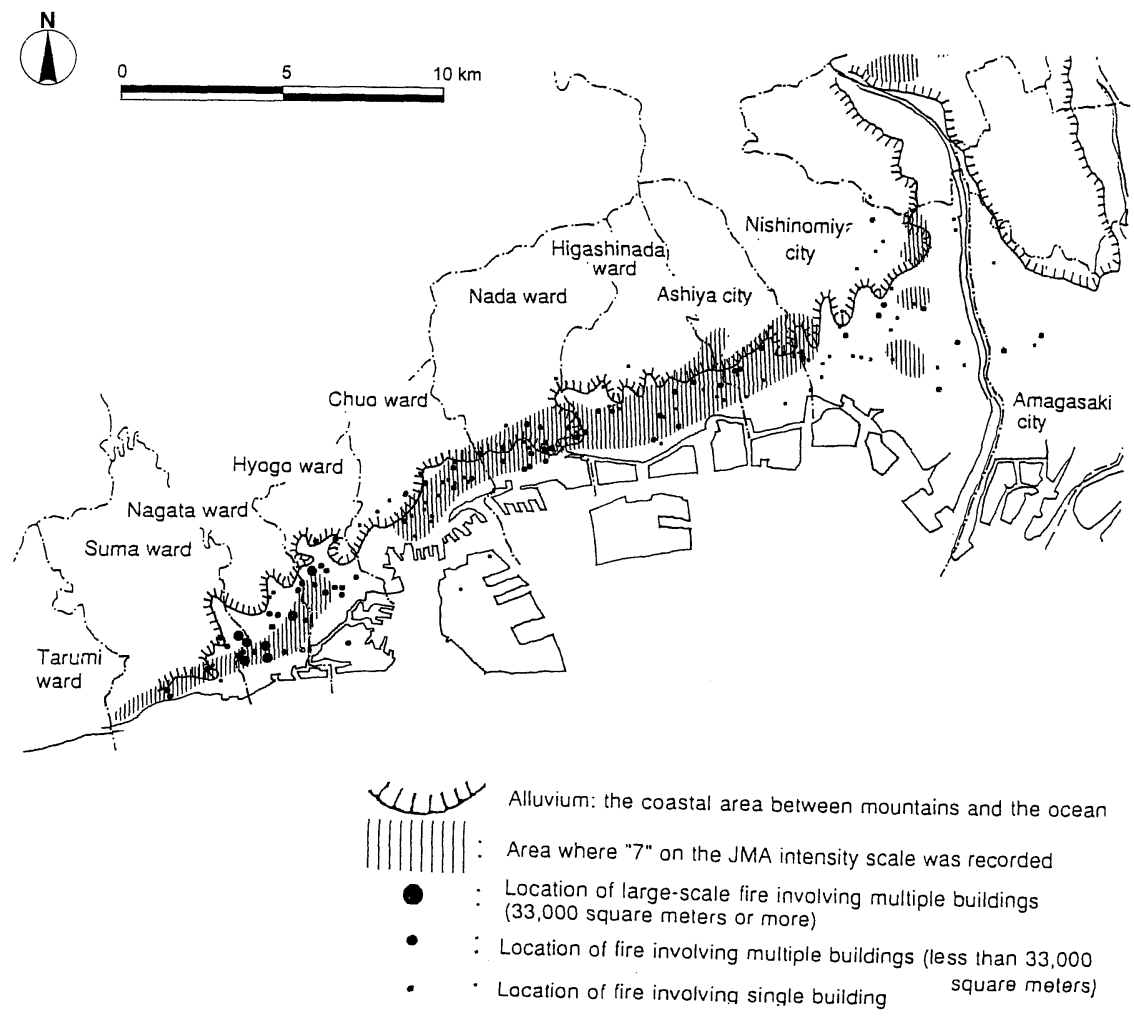

FIGURE 1. Location of buildings surveyed for fire damage ( also shows the alluvium extending from Kobe to Amagasaki and the area where " 7 " on the JMA intensity scale was recorded ) 


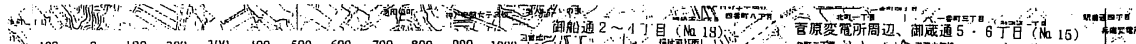
1)

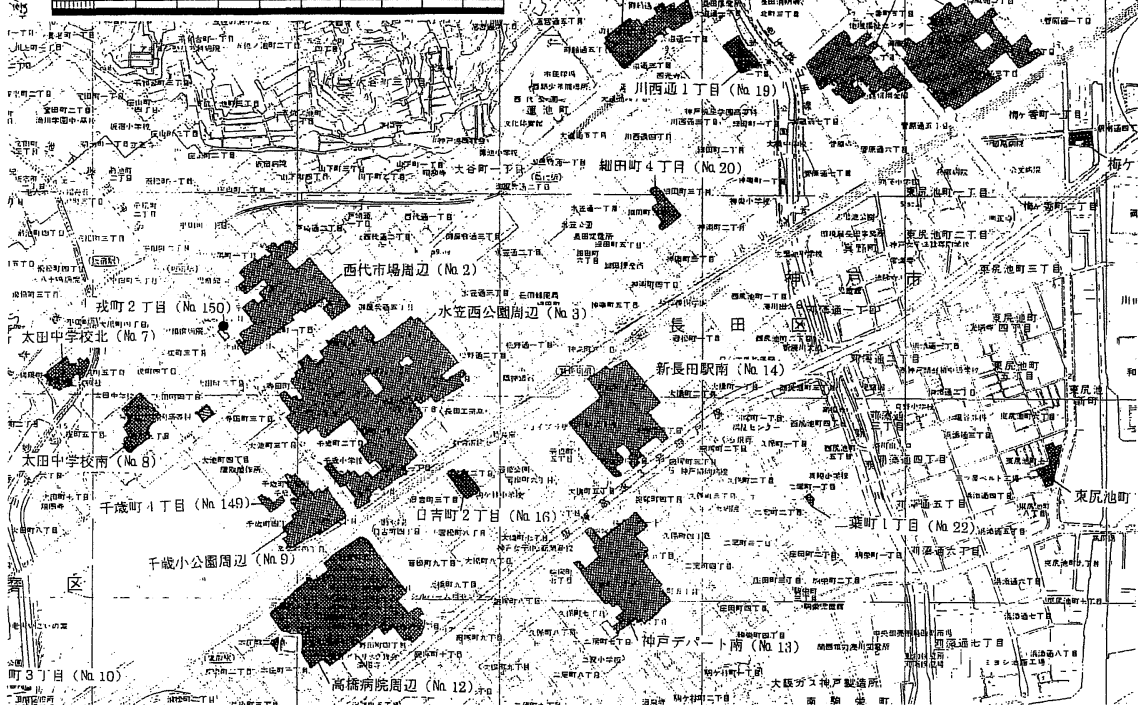

\section{Nagata and Suma Wards}

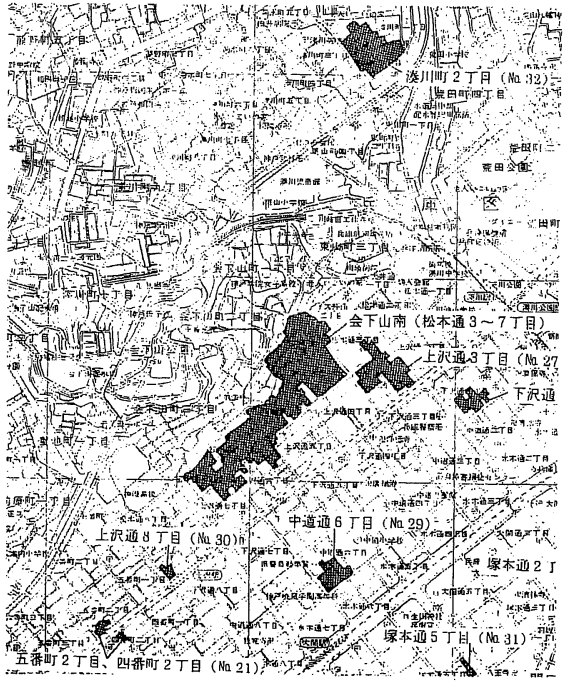

Hyogo Ward

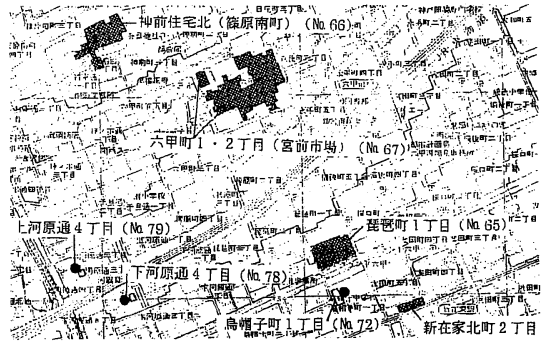

\section{Nada Ward}

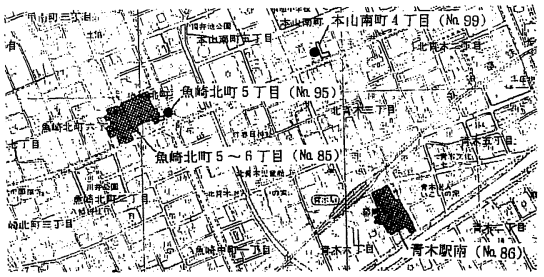

Higashi-Nada Ward

FIGURE 2. Large Conflagrations in Kobe City 


\section{VELOCITY OF FIRE SPREAD AND WIND}

Figure 3 shows an example of fire spread recorded by news videos. Fire spread was relatively slow, averaging about 20 to 30 meters per hour. The main reason for this slow speed was that there was a slow wind and sometimes no wind on the day of the earthquake as shown in Figure 4. The average wind velocity in Kobe was $2.6 \mathrm{~m} / \mathrm{s}$ on 17 January 1995.

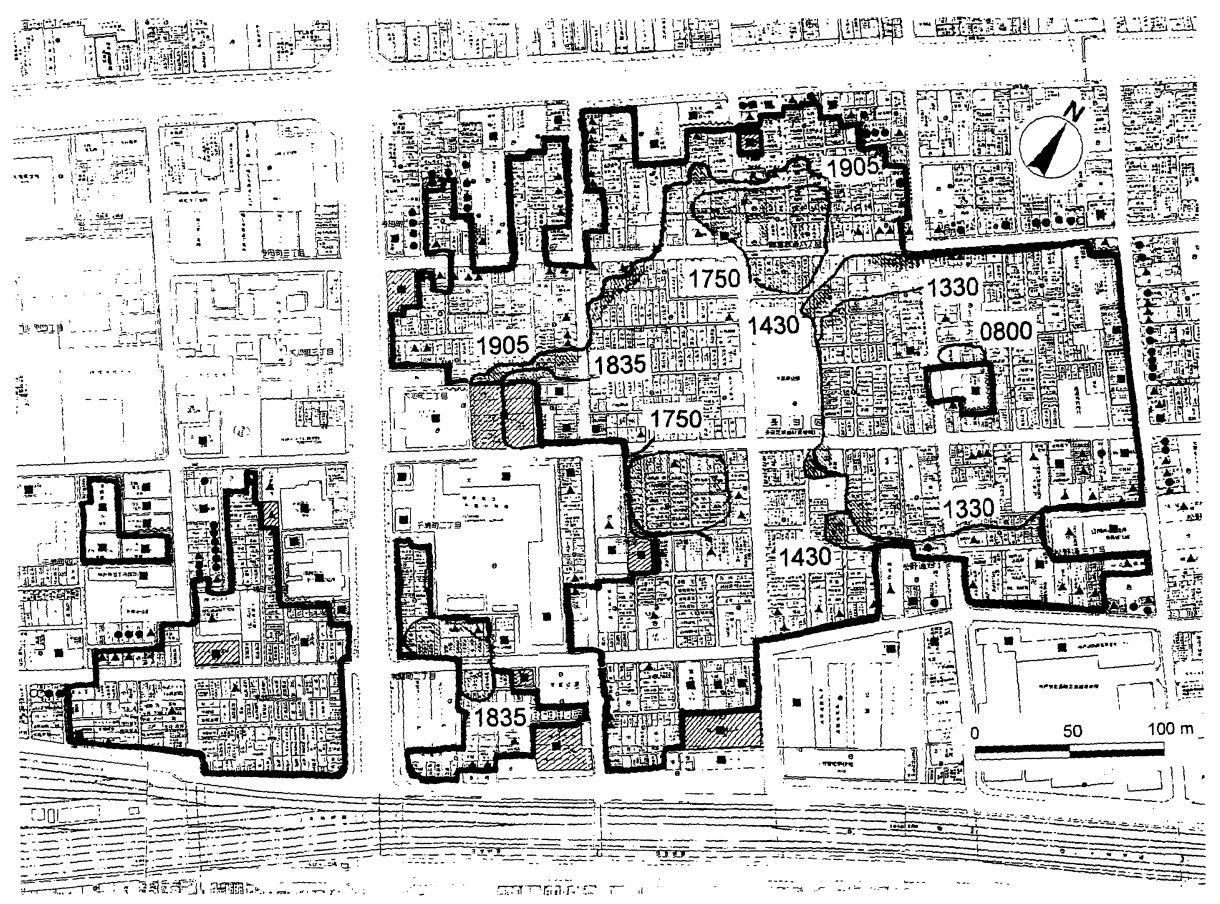

: Partially burned building

: Area burned at the same time

: Contour lines at the indicated times ( 17 January 1995 )

: Fire spread boundaries

Index for building structure (All the roofs were non-combustible.)

- : Fireproof building

A : Semi-fireproof building

- : Wooden building with non-combustible materials on the exterior wall

$\circ$ : Wooden building without non-combustible materials on the exterior wall

FIGURE 3. Contour Line of Fire Spread (Fire Site around Mizukasa Nishi Park ) 


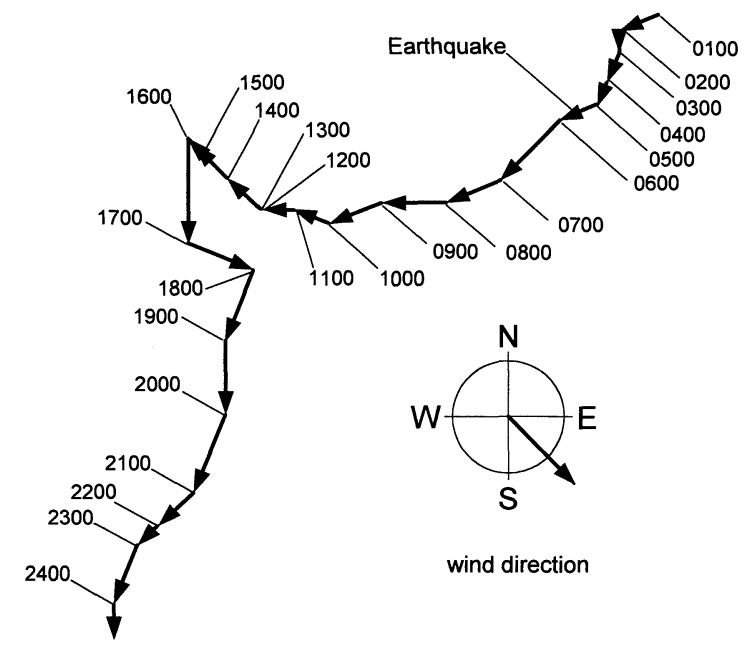

FIGURE 4. Wind Velocity Vectors recorded at Kobe Meteorological Observatory in Chuo Ward for the Day of the Earthquake, 17 January 1995. The wind direction is indicated by the compass rose. The wind speed is given by the length of the velocity arrow, with the arrow in the compass rose corresponding to $5 \mathrm{~m} / \mathrm{s}$. See Table 2 for temperature and relative humidity.

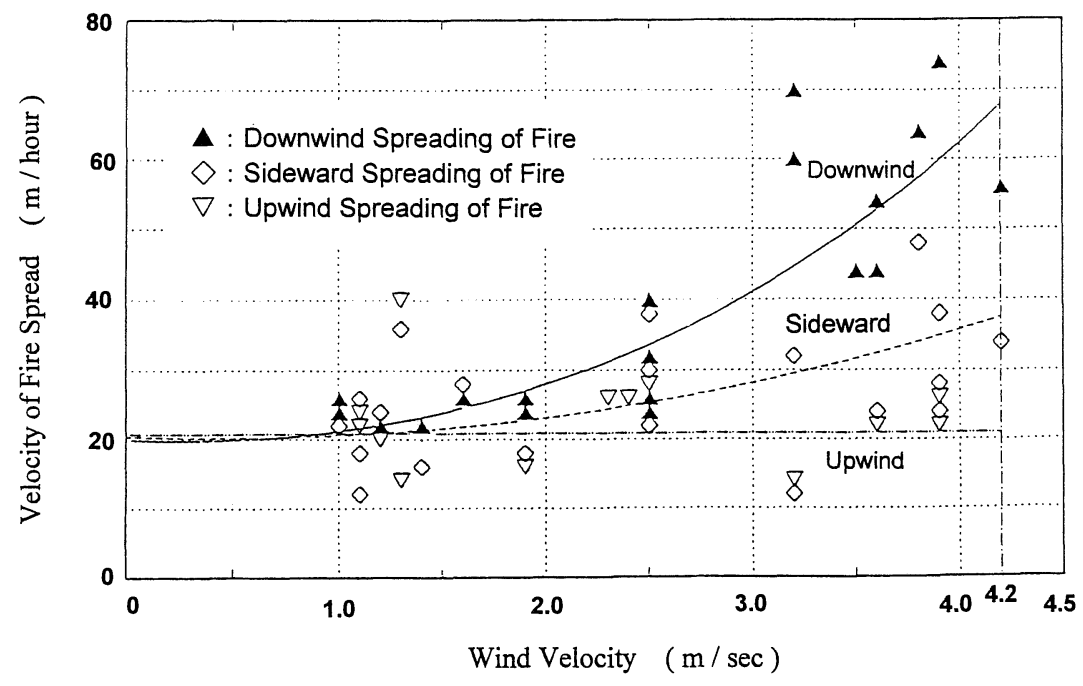

FIGURE 5. Relation between the wind velocity and the velocity of fire spread ${ }^{4)}$ 
Figure 5 indicates the relation between the wind velocity and the velocity of fire spread. When the wind velocity is higher than $3 \mathrm{~m} / \mathrm{s}$, the velocity of the downwind fire spread increases significantly. For each $1 \mathrm{~m} / \mathrm{s}$ increase in wind speed above $2 \mathrm{~m} / \mathrm{s}$, the downwind fire spread increases by $20 \mathrm{~m} / \mathrm{hr}$.

There is some evidence that the fire spread faster in the blocks of wooden buildings without non-combustible materials on the exterior wall than in the blocks of wooden buildings with non-combustible materials and in the blocks which have some fire resistive buildings ${ }^{5)}$.

\section{FIRE SPREAD MECHANISMS}

The fires spread widely because the buildings were so close together especially in Nagata and Hyogo wards as shown in Figs 6,7 and 8. In those fire sites in Nagata and Hyogo wards, there were many wooden dwellings whose exterior walls were not covered with noncombustible materials. Although many of the conventional post $\&$ beam construction dwellings had been covered with non-combustible materials, they were severely damaged by the earthquake. Where fire protected wooden buildings were constructed appropriately in accordance with the present seismic standards and therefor suffered a little damage, most of them that caught fire did so mainly because of fire spread through the building's openings, not due to their walls ${ }^{6)}$.

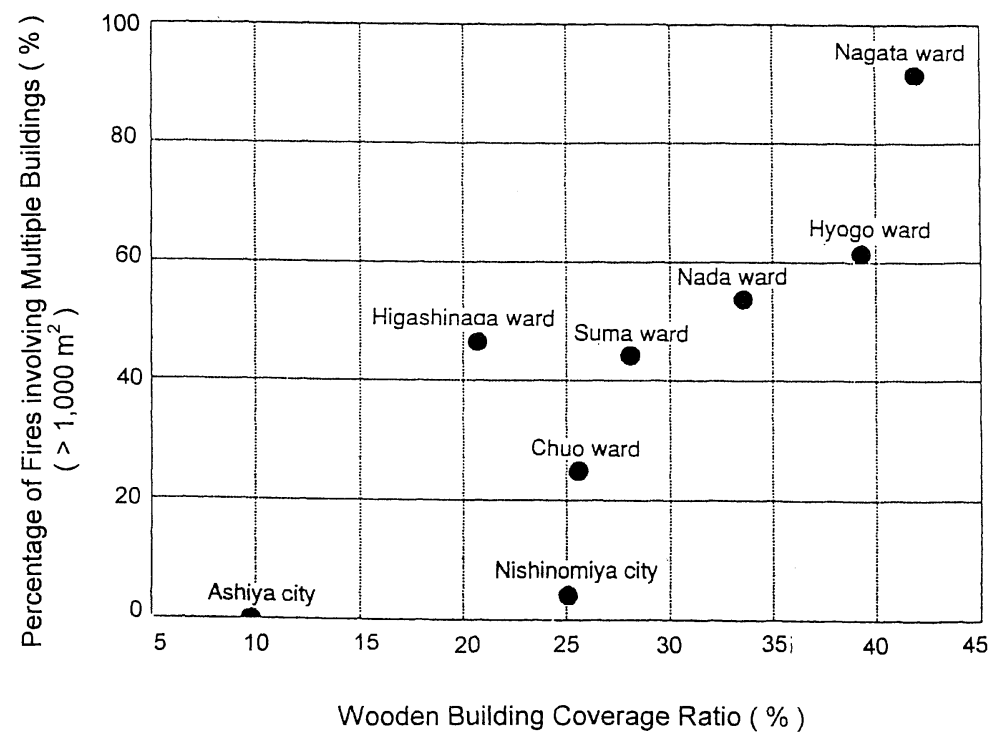

FIGURE 6. Relation between Percentage of Fires Involving Multiple Buildings and Wooden Building Coverage Ratio ( Ward and City ). Wooden Building Coverage Ratio is ratio between area of wooden buildings and area of all housing lots including housing lots for fireproof buildings. 


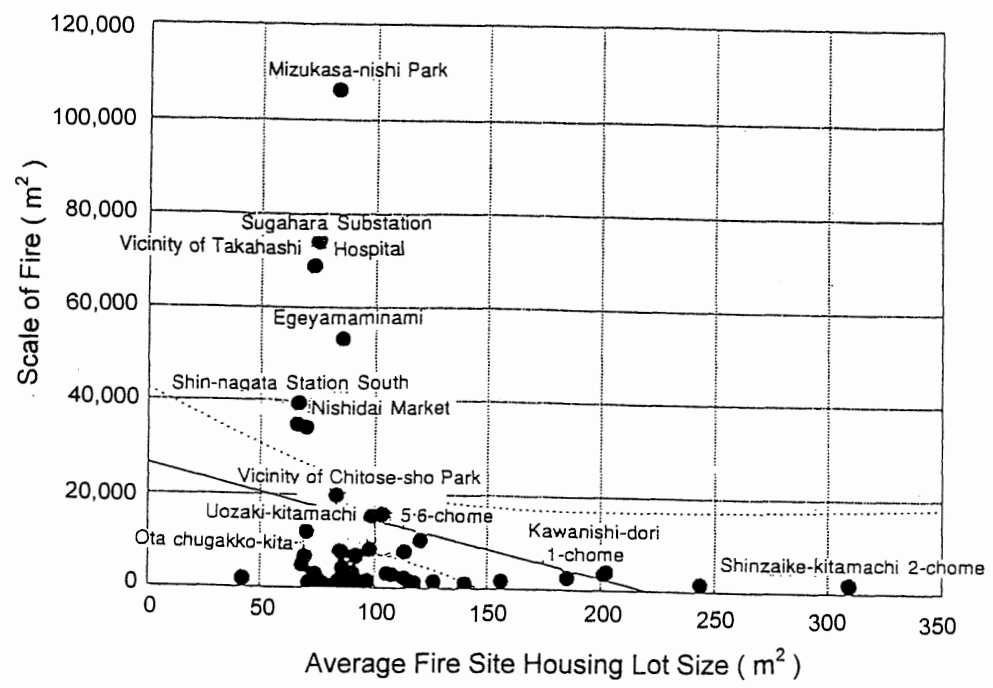

FIGURE 7. Relation between Scale of Fire and Average Fire Site Housing Lot Size.

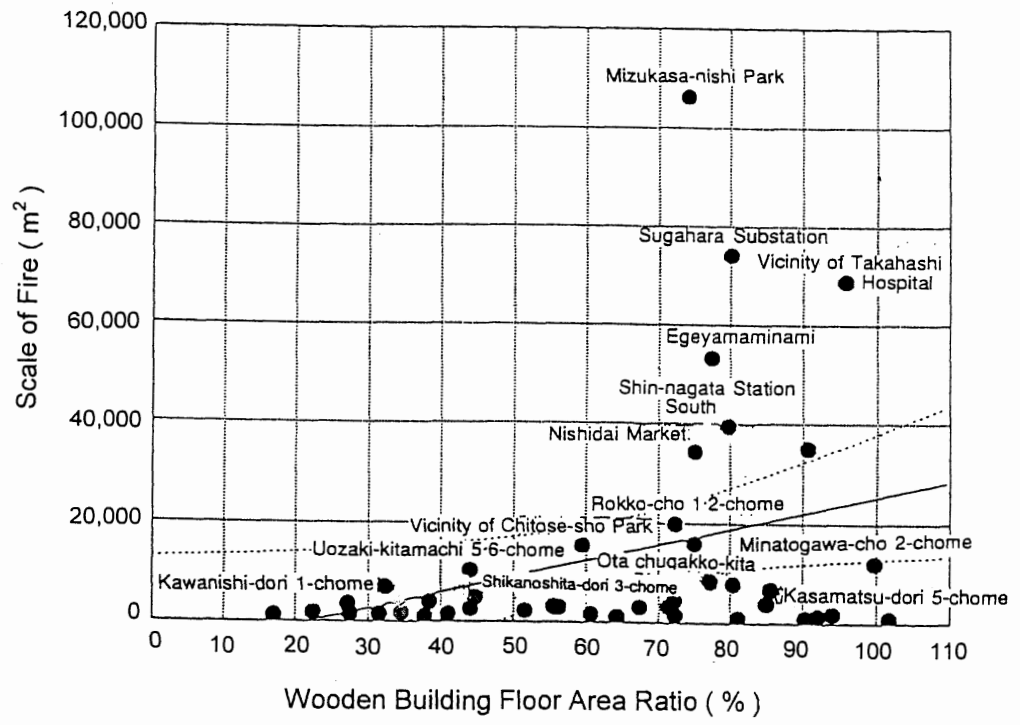

FIGURE 8. Relation between Scale of Fire and Fire Site Wooden Building Floor Area Ratio. Wooden building floor area ratio is ratio between floor area of wooden Buildings and area of all housing lots including housing lots for fireproof buildings. 


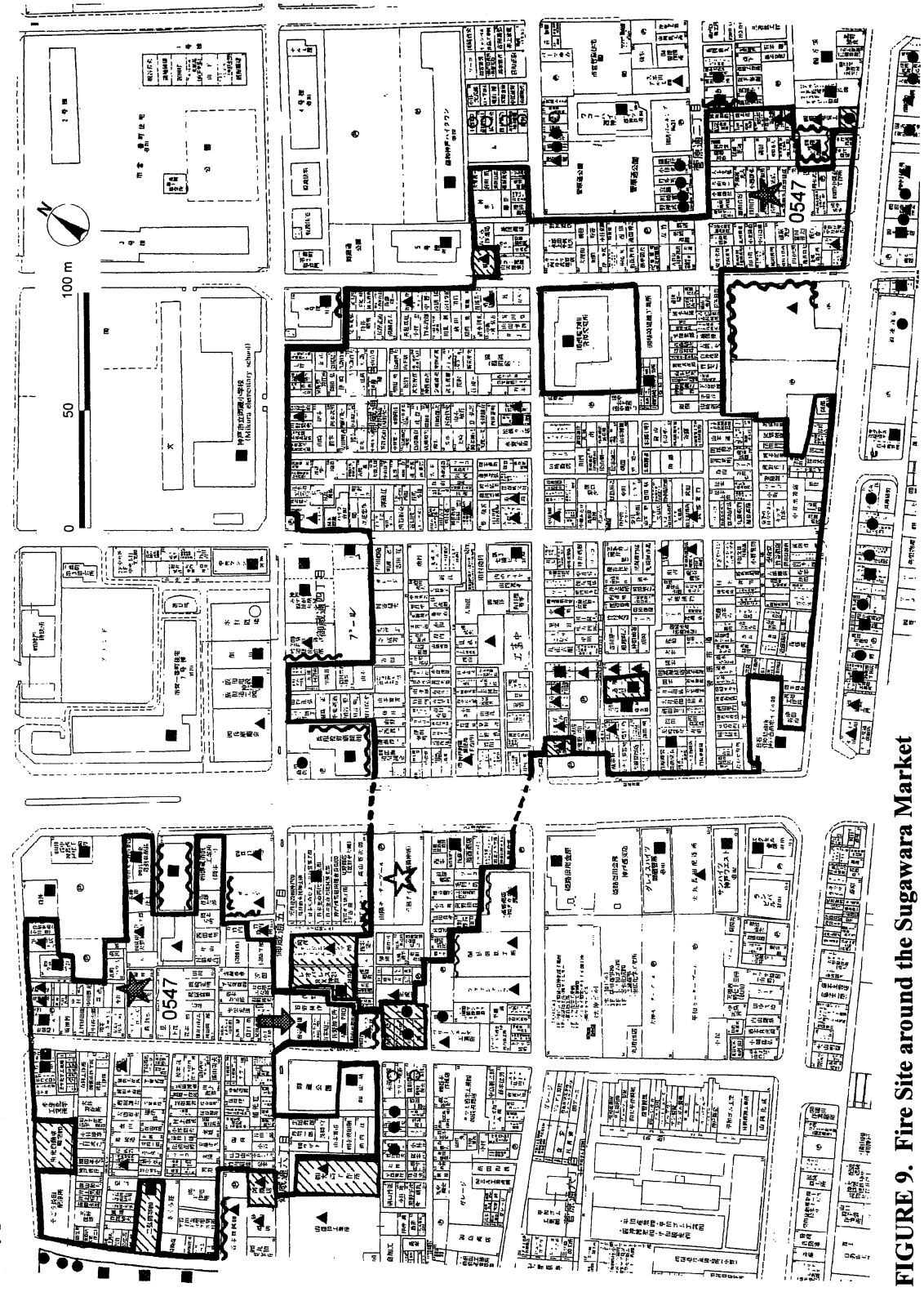


Index for building structure (All the roofs were non-combustible.)

- : Fireproof building

A : Semi-fireproof building

- : Wooden building with non-combustible materials on the exterior wall

$\circ$ : Wooden building without non-combustible materials on the exterior wall

Index for Ignition and Fire Spread

: Fire origin ( an eye-witness )

: Ignition by burning wood and embers flying through the air

( Estimated by the evidence of sight )

: Fire Spread through the collapsed building on the street by fire

Index for Fire-Arresting Line

- Fire spread boundaries

एIIIs: Partially burned building

m: Fire damage only on the exterior wall

\section{FIGURE 9. Fire Site around the Sugawara Market ( continued )}

The combustible contents of the houses, synthetic rubber in small shoes factories especially in Nagata ward and collapsed buildings on the street contributed to the fire spread as shown in Figure 9.

There are at least 20 cases where new ignitions were caused by burning wood and embers flying through the air ${ }^{7)}$. Because fireproof roofing was shaken down by the earthquake, Ignition occurred by burning wood and embers in those wooden house areas, although people out there extinguished most of the small ignitions.

\section{FIRE STOP FACTORS}

Most of the cease-burning lines in urban areas were wide streets, railways, parks and similar large spaces, rows of buildings of fireproof construction, and fire proof buildings constructed on large building lots.

Figure 10 shows fire-stop elements at the fire site around the Mizukasa Nishi Park. This fire site was a typical residential area with large concentrations of wooden houses. About 60 percent of the cease-burning lines consisted of fireproof buildings.

Figure 11 shows a comparison between the result of the Building Research Institute (BRI) investigation and the Fire Research Institute (FRI) investigation at Mizukasa Nishi Park ${ }^{8)}$. To use the same definitions, space factors around the park were omitted from the result of the FRI investigation.

The streets \& railways factor is the main fire-stop factor at the FRI investigation. The fireproof buildings factor is the main fire-stop factor at BRI investigation. Had the buildings along the $6-8 \mathrm{~m}$ wide streets been wooden buildings, those wooden buildings at the cease- 
burning lines would have been easily ignited. From this point of view, improvement of fire protection of buildings is more important than street widening.

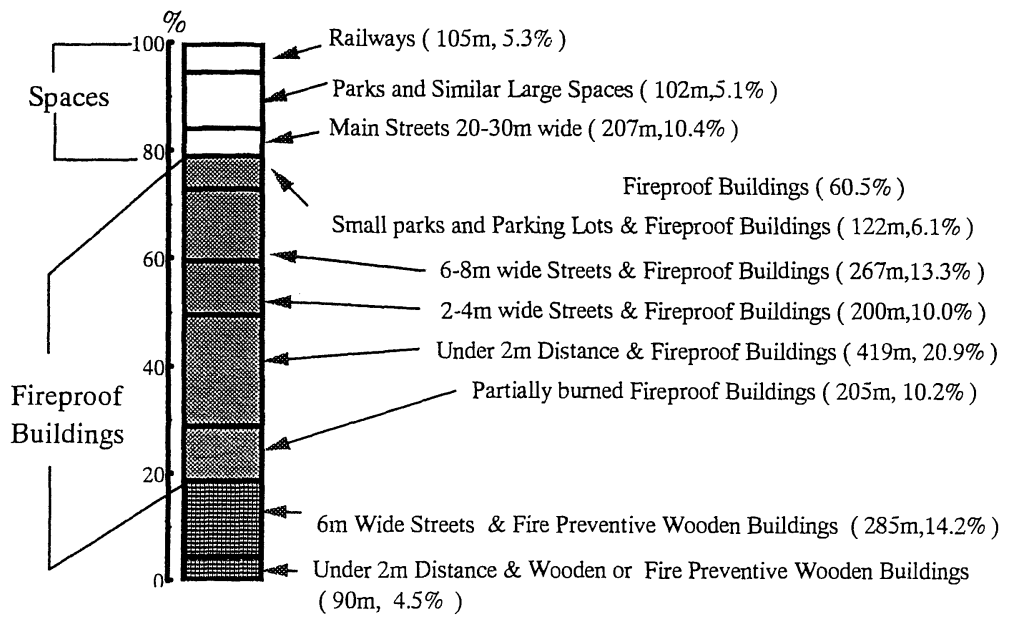

FIGURE 10. Fire Stop Elements at the Fire Site around the Mizukasa Nishi Park ( BRI )
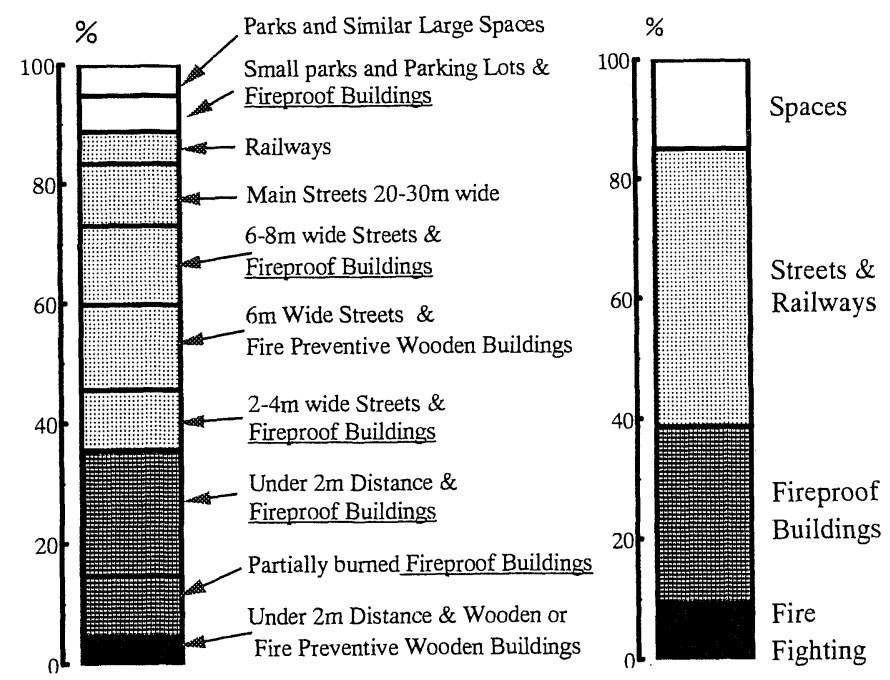

(BRI Investigation)

(FRI Investigation)

FIGURE 11. Fire Stop Factors Comparison between the result of BRI investigation ${ }^{3)}$ and FRI investigation at the Fire Site around the Mizukasa Nishi Park ${ }^{8)}$ 


\section{CONCLUSION}

Fortunately the wind was weak during the first hours after the earthquake and catastrophic fires such as the 1923 Great Kanto Earthquake Fire were avoided. Further studies including detailed analysis of fire spread mechanisms and experimental studies for the conditions with strong winds are necessary for the disaster prevention planning. It is necessary to promote the improvement of urban residential areas by, for example, carrying out the systematic reconstruction of buildings in areas with high concentrations of decrepit wooden dwellings.

\section{REFERENCES}

1. Yoshiyuki Matusbara, Keiko Suzuki, "Occurrences of Fires following the earthquake", in A Report on Fires following the Hyogo-ken Nanbu Earthquake of 1995, pp.32-40, Japan Association for Fire Science and Engineering, 1996 ( in Japanese ).

2. Fire Department of Kobe City, A Report on Fires following the Hyogo-ken Nanbu Earthquake of 1995, 1995 (in Japanese ).

3. Akihiko Hokugo, "The Performance of Fire Protection of Buildings against the Fires following the Hyogo-ken Nanbu Earthquake", in A Survey Report for Building Damages due to the 1995 Hyogo-ken Nanbu Earthquake, Building Research Institute, 1996.

4. Tokyo Fire Department, The Investigation Report on the Fires in Kobe City following the Hyogo-ken Nanbu Earthquake of 1995, 1995 ( in Japanese ).

5. Yoshiteru Murozaki at Kobe Univ. and Institute of Environment \& Safety Planning, $\underline{A}$ Report on Fire Spread in the 1995 Great Hanshin and Awaji Earthquake, 1995 ( in Japanese ).

6. Sugawara Shinichi, Damages at the openings of Houses by the fires following the Hyogo-ken Nanbu Earthquake of 1995, in The Textbook for the $34^{\text {th }}$ Fire Science

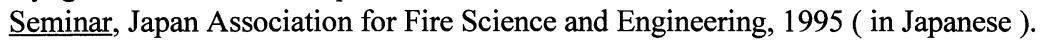

7. Murozaki Yoshiteru, "Problems around the fires following the Hyogo-ken Nanbu Earthquake of 1995", in Proceedings of the Symposium on Earthquake and Fires, Japan Association for Fire Science and Engineering, 26 May 1995 ( in Japanese ).

8. Ai Sekizawa, "Fire Stop Factors of the Fires following the Hyogo-ken Nanbu Earthquake of 1995", Fire Science and Information, No.40, Center for Fire and Disaster Preparedness, 1995 ( in Japanese ). 